\title{
URETHRAL PRESSURE MEASUREMENT AFTER DIVISION OF THE EXTERNAL SPHINCTER
}

\author{
By B. J. Abel, F.R.C.S., J. Cosbie-Ross, F.R.C.S., N. O. K. Gibbon, F.R.C.S. \\ and R. M. JAMESON, F.R.C.S.
}

The Liverpool Regional Paraplegic Centre, Southport, England

\section{INTRODUCTION}

Division of the external sphincter was introduced into paraplegic urology 18 years ago. The early operations were reserved for non-spastic sphincter obstructions but its benefit in spastic obstruction was soon realised. Reports from centres at home and abroad have confirmed the early Southport experience that the operation is safe and effective (Ross et al., 1958, 1967).

Using a Collings diathermy knife through a panendoscope posterobilateral incisions are made from the level of the verumontanum downwards for approximately three centimetres, dividing the muscular wall of the urethra subtotally.

This paper reports the effect of this technique on the resistance offered by the urethral sphincter in both the short- and the long-term.

\section{PATIENTS AND METHODS}

Traditionally urethral resistance estimation has relied upon water column monometry (Ross \& Tinlker, 1959; Lapides, 1960; Draper, 196I) or air manometry (Kleeman \& Chute, 1967). Such techniques give a measurement of total urethral resistance and give no information on the contribution of the 'sphincter' alone. In addition errors arise from slow response and an indefinite end-point.

The introduction of the Urethral Pressure Profile Catheter by Brown and Wickham in 1969 solved these problems (Brown \& Wickham, 1969; Harrison \& Constable, 1970). The pressure gradient from the bladder, through the sphincter and along the urethra can be obtained during slow withdrawal of this catheter. Note that the total sphincter pressure is recorded; that is the sum of elastic tissue, smooth muscle and striated muscle components. The latter accounts for 20 per cent of the total pressure.

A group of 30 patients were studied and the following investigations were carried out; residual urine estimation; filling and voiding cystometrogram; urethral pressure profile and, for comparison, retrograde urethral resistance using a water column. The DISA uroflow apparatus with an XY recorder was used for the pressure measurements. Sphincter electromyography was used to check that catheter movement per se did not trigger sphincter contraction.

Of the 30 patients studied, the first i 5 patients underwent sphincter division 6-16 years ago; the remaining I5 patients underwent sphincter division between four months and three years ago (Table I). 
TABLE I

\begin{tabular}{|l|c|c|}
\hline & \multicolumn{2}{|c|}{ Patients (30) } \\
\hline & Early group (I5) & Late group (I5) \\
\hline $\begin{array}{c}\text { Age (average) } \\
\text { Time since sphincter division } \\
\text { (average) }\end{array}$ & 48 years (35-72) & 32 years (I8-6I) \\
\hline
\end{tabular}

In this late group both pre-operative and post-operative tests were carried out allowing the extent of sphincter pressure reduction by operation to be studied. In the early patients the permanence of such a pressure reduction could be studied. The levels of cord lesions and incidence of detrusor contractions are shown in Table II.

TABLE II

Level of lesion

\begin{tabular}{|l|c|c|}
\hline & Early group & Late group \\
\hline Cervical & 4 & 9 \\
Thoracic & 9 & 5 \\
Lumbar & I & I \\
Detrusor contractions present & 8 & I2 \\
\hline
\end{tabular}

\section{RESULTS}

The profile catheter gave a quick and positive result on the completeness of sphincterotomy in all cases.

In a complete operation there should be no suggestion of a pressure rise in the sphincter area, merely a flat trace along the whole urethral length. This 'plateau pressure' is below $35 \mathrm{~cm}$. of water and is not increased during flexor spasms. degree.

In an incomplete division a pressure peak is present, often amputated to a

The average resting pre-operative sphincter pressure in the late patients was $80 \mathrm{~cm}$. of water (range $50-100 \mathrm{~cm}$.) Similar figures are found in the normal population. In all the operations a sphincter pressure reduction was achieved. The average reduction by operation was $50 \mathrm{~cm}$. of water (range $15-75 \mathrm{~cm}$.) using the urethral profile technique (Table III). The reduction using retrograde urethethrometry was $47 \mathrm{~cm}$. water (range $20-75 \mathrm{~cm}$.), considerably more than that reported by Currie and Bunts (1970) and Schellhamer et al. (1974).

A complete sphincterotomy after a single operation was found in eight of the 
TABLE III

Sphincter pressure

$\begin{array}{ll}\text { Pre-operative (average) } & 80 \mathrm{~cm} . \text { (range } 50-100 \mathrm{~cm} .) \\ \text { Reduction by operation (average) } & 50 \mathrm{~cm} . \text { (range } 15-75 \mathrm{~cm} . \text { ) }\end{array}$

TABLE IV

Completeness of sphincterotomy on profile

\begin{tabular}{|l|c|c|}
\hline & Early group & Late group \\
\hline After first operation & 8 & I I \\
After second operation & 6 & I \\
Still incomplete & I & 3 \\
\hline
\end{tabular}

early group and II of the late group. After a second attempt six patients in the early group and one in the late group had complete divisions (Table IV).

There remains one patient (G. H.) in the early group with an incomplete operation whose sphincter pressure is $65 \mathrm{~cm}$. water (fig. I). Despite an absence of detrusor contractions this patient voids efficiently by powerful abdominal straining; he has a residual urine of $30 \mathrm{ml}$. and no upper tract dilatation. His operation, although incomplete, has freed him from a catheter.

\section{The Incomplete Operations}

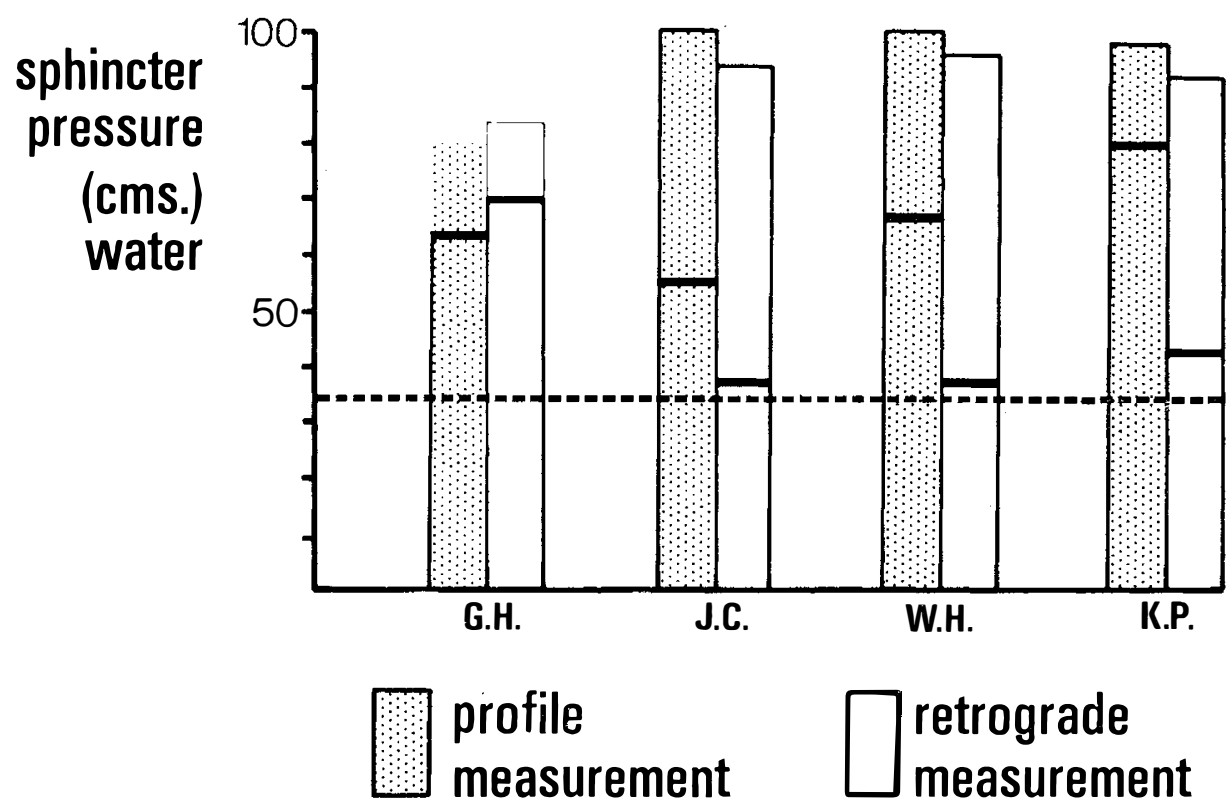

FIG. I

$\mathrm{I} 3 / \mathrm{I}-\mathrm{D}$ 
There remain three patients in the late group with definitely incomplete operations on profile measurement (fig. I). Retrograde measurements in these patients suggested complete sphincter division. One patient (K. P.) who, for technical reasons had a partial sphincter division only, has regained reflex pelvic floor relaxation during voiding. He has a sterile residual urine of $75 \mathrm{ml}$. with normal upper tracts.

The second patient (W. H.) has a sphincter pressure of $70 \mathrm{~cm}$. of water after one operation (pre-operative pressure $100 \mathrm{~cm}$.) with a large residual urine and normal upper tracts. He has been made catheter free by operation but he has obstructed voiding and is under careful observation.

The third patient (J. C.) had complete retention of urine with a sphincter pressure of $100 \mathrm{~cm}$. before operation. His post-operative sphincter pressure is $55 \mathrm{~cm}$. of water. He continued with a large infected residual urine and developed bilateral ureteric reflux. Despite bilateral ureteric reimplantation and good detrusor contractions the large infected residual urine persists and a further sphincter division is required.

This is the only patient in this series who shows a clear deterioration in renal function. All the other patients have, so far, maintained or improved their renal function.

In particular, eight patients, despite high-level lesions and absent detrusor contractions, have satisfactory and stable renal function and are catheter free.

In all patients residual urine estimation correlated well with bladder activitygood detrusor contractions giving a small residual urine. However no correlation was found between the size of the residual urine and the completeness of sphincter division.

In the above series only one patient continues with a catheter-this is because of condom difficulties related to a small phallus.

Finally the safety of the procedure should be stressed. There has been no operative mortality from sphincter division at the Southport Unit for the past I6 years.

\section{SUMMARY}

The completeness and permanence of 'division of the external sphincter' is assessed in a group of 30 spinal injury patients.

The urethral pressure profile technique is effective in estimating the completeness of the operation.

Both in the short-term and the long-term (four months to I6 years) the results of the operation are excellent with no mortality.

Acknowledgements. We wish to thank the Merseyside Association for Kidney Research; Mr. K. R. Krishan, Consultant in Charge of the Centre; Mr. Goldbourne and nursing staff of the Centre and our secretaries Miss C. Magalione and Miss J. Glover for their help.

\section{REFERENCES}

Brown, M. \& Wickham, J. E. A. (1969). The urethral pressure profile. Brit. F. Urol. 40, 2 I I-2I7. 
CURRIE, R. J., Bunts, R. C. et al. (I970). External sphincterotomy in paraplegics: technique and results. F. Urol. 103, 64-68.

Draper, J. W. (I96I). Measurements of urethral resistance. F. Urol. 85, 586.

HARRISON, N. W. \& Constable, A. R. (I970). Urethral pressure measurement. A modified technique. Brit. F. Urol. 42, 229-233.

KLEEMAN, F. J. \& CHUTE, R. A. (I967). A plan for the evaluation of patients with bladder dysfunction. F. Urol. 97, I029.

LAPIDES, J. et al. (I960). Further observation on the kinetics of the urethrovescical sphincter. 7. Urol. 84, 86.

Ross, J. C., GibBon, N. O. K. \& Damanski, M. (1958). Divisions of the external urethral sphincter in the treatment of the paraplegic bladder. Brit. F. Urol. 30, 204.

Ross, J. C., Gibbon, N. O. K. \& Damanski, M. (1967). Division of the external sphincter in the treatment of the neurogenic bladder. Brit. F. Surg. 54, 627.

Ross, J. C. \& TinkLeR, L. (1959). Some common complications after prostatectomy. Brit. Med. Fournal, 2, 663-666.

SChEllhamer, P. F., HACKLER, R. H. \& Bunts, R. C. (1974). External sphincterotomy: rationale for the proceedure and experience with I50 patients. Paraplegia, 12, 5-I4. 